\title{
Paediatric trained district nurse in the community : expensive luxury or economic necessity?
}

\author{
J D ATWELL, MARGARET A GOW
}

In 1969 a paediatric trained team of district nurses was established in Southampton to look after children at home after operations performed on a day basis. ${ }^{1}$ Initially, there were two district nurses, but the number has since increased to five. This is because of the increasing number of day cases and new developments in the paediatric service available in the community. ${ }^{23}$ In 1968 home care paediatric nursing was started in Edinburgh and the service there now consists of four hospital and two community based nurses. In Birmingham and Gateshead there is a community based service; the service in Gateshead started in 1974. The community nurses in Gateshead are not trained to look after children. They look after medical patients who have been discharged home early or are direct referrals from general practitioners. In Manchester at Booth Hall Children's Hospital a service was started in August 1984 with one nurse in the community who has hospital as well as community commitments. Few published data exist on the service provided in these schemes apart from the experience of $\mathrm{St}$ Mary's Hospital, London, ${ }^{4}$ and our own scheme in Southampton. ${ }^{1-3}$

In Southampton the community paediatric sister is now an essential link between the primary health care team and the secondary care provided by the hospital. This paper discusses the role of the sick children's nurse who is community trained with particular reference to avoiding or reducing the length of stay in hospital.

There are many advantages of avoiding an inpatient admission, and although a single admission to hospital is not associated with any marked psychological disturbance it is often a traumatic experience for the child especially as $50-60 \%$ of children admitted for general surgical operations are under the age of $5 .^{5}$ Other advantages are a possible reduction in the number of inpatient hospital beds, integration of the hospital and community services, cost effectiveness of treatment, reduction in waiting list time, early discharge of patients, reduced risks of cross infection, and the possibility of avoiding admitting day patients to inpatient wards. There must be an efficient service for nursing children at home to achieve these advantages.

\section{Functions of the paediatric and community trained sister}

Although the service was initially established to look after children after surgical operations performed on a day basis, ${ }^{1-4}$ 67 other functions of these nurses have evolved.

\footnotetext{
Wessex Regional Centre for Paediatric Surgery, Southampton General Hospital, Southampton SO9 4XY

J D ATWELL, MB, FRCs, consultant paediatric and neonatal surgeon MARGARET A GOW, RSCN, RGN, paediatric home nursing sister Correspondence to: Ms Gow.
}

\section{POSTOPERATIVE CARE OF DAY SURGICAL PATIENTS}

Day surgery has been defined as "attending as a non-resident patient for an operative procedure which requires some form of supervision, preparation, or period of recovery involving the provision of accommodation and services."' 8 The length of stay for day surgery may vary from 24 hours to only a few hours. In our children's day ward there are 10 lists a week (seven surgical, one orthopaedic, one dental, and one medical oncology)-that is, the children spend approximately six hours in hospital.

There has been a twofold increase in the number of day surgical operations-that is, from 648 in 1970 to 1257 in 1983. The proportion of day surgical operations compared with inpatient operations has also increased during this time from $32 \%(1970)$ to $50 \%$ (1983). All the operations have been performed under general anaesthesia and $60 \%$ of the patients undergoing surgery have been under 5 years. The number and type of operation performed in 1983 and 1984 is shown in table I. Since 1969 over 13000 children have been treated

\begin{tabular}{|c|c|c|}
\hline Operation & 1983 & 1984 \\
\hline \multicolumn{3}{|l|}{ Hernia : } \\
\hline Inguinal & 203 & 207 \\
\hline Epigastric & $\begin{array}{l}41 \\
10\end{array}$ & 51 \\
\hline Undescended testes & 125 & 149 \\
\hline $\begin{array}{l}\text { Circumcision } \\
\text { Meatotomy }\end{array}$ & 287 & 320 \\
\hline $\begin{array}{l}\text { Meatotomy } \\
\text { Separation of preputial adhesions }\end{array}$ & $\begin{array}{l}18 \\
39\end{array}$ & $\begin{array}{r}9 \\
70\end{array}$ \\
\hline $\begin{array}{l}\text { Separation of preputial adhesions } \\
\text { Tongue tie }\end{array}$ & 22 & 27 \\
\hline Cystoscopy & 111 & 103 \\
\hline \multirow{2}{*}{$\begin{array}{l}\text { Examination under anaesthesia; } \\
\text { sigmoidoscopy } \\
\text { Miscellaneous }\end{array}$} & & \\
\hline & $\begin{array}{r}49 \\
314\end{array}$ & $\begin{array}{r}55 \\
206\end{array}$ \\
\hline Total & 1257 & 1321 \\
\hline
\end{tabular}

successfully in this way. This includes 1034 orchidopexies, 2156 herniotomies, 3270 circumcisions, and 1937 endoscopies. The success of operations performed on a day basis depends on selection of the operative procedure and patient, expert paediatric anaesthesia, nursing, and support for the family in the community.

\section{NURSING OF PATIENTS DISCHARGED HOME EARLY}

The policy is for medical and surgical patients to be discharged home at the earliest opportunity. The provision of a nursing service for children in the community has allowed even earlier discharges-for example, in children after an uncomplicated appendicectomy it is safe to discharge them within the first three postoperative days. This has reduced the average length of stay from 8.75 days to 4.55 days. $^{2}$ A similar policy may be used in the management of children admitted with gastroenteritis and pneumonia. 


\section{CARE OF CHILDREN WITH HANDICAPS}

In any large urban community there are a considerable number of children with physical handicaps-for example, spina bifida, cerebral palsy-and children with either a temporary or a permanent colostomy or urinary diversion. The parents require physical and emotional support to help them look after their children-for example, bathing, feeding, prevention of pressure sores, control of constipation. The home paediatric nursing team can help in their management and liaise with the district handicap team under the direction of the community paediatrician. This will help to improve the standard of the care of these children.

\section{CARE OF CHILDREN WITH MALIGNANT DISEASE}

One of the biggest changes in the role of the community paediatric sister has been the participation in the management of children with malignant disease. There have been two separate roles, firstly, with support to the families and, secondly, with administration of chemotherapy and terminal care.

\section{GENERAL PRACTITIONER REFERRALS}

Hospital admission for a child can often be avoided provided that the general practitioner has additional nursing support in the child's home-for example, administration of intramuscular injections of antibiotics, management of severe constipation with enemas, aperients, and bowel training.

\section{LIAISON BETWEEN THE COMMUNITY AND THE HOSPITAL}

One of the community paediatric sister's most important roles is that she provides the key link in the chain of secondary care in the hospital and the primary health care team. There must be ready access to the hospital for these sisters-that is, visiting patients in the day ward and attending inpatient ward rounds on a regular basis. In this way they become essential and important members of both teams.

\section{TEACHING}

The importance of the community aspects of care is now well recognised. In the 13 month registered sick children's nurse training a period of eight weeks is spent in the community. This includes three weeks with the community paediatric sister, two weeks on the day ward, two weeks with a health visitor, and one week with a school nurse.

\section{Analysis of home visits by the community paediatric sisters}

Since 1979 the community paediatric sisters have recorded their home visits separately from the general district nurses. The number of home visits has increased from 6479 in 1979 to 7871 in 1983. In an analysis of 631 visits over a one month period in 1983 there were 469 visits to day surgical patients, 110 to medical patients, and 52 to oncology patients. This excludes any visits related to terminal care, which although infrequent naturally result in an increase in the number of visits.

\section{Cost of the service}

There are two main economical advantages of performing surgery on a day basis. Firstly, it is cheaper if inpatient beds are closed. Secondly, if inpatient beds are not closed productivity may be increased. This second method of management would be more expensive but even so the cost per operative procedure is reduced. ${ }^{9}$

In 1983 the cost of a one day stay in hospital was $£ 123$. This contrasts markedly with the cost of a visit by a community paediatric sister at $£ 6.94$. The total cost of the service provided by the community paediatric sisters in Southampton is $£ 55000$ a year and the cost of the nursing and clerical services in the paediatric day ward is $£ 30000$ a year. Thus the total community and hospital costs for the provision of the service is $£ 85000$ a year (table II).

TABLE II-Cost of providing day surgical care

\begin{tabular}{|c|c|c|}
\hline $\begin{array}{l}\text { Community costs } \\
\text { Clinical nursing officer }(25 \% \text { salary }) \\
\text { Community paediatric nurses }(5 \times £ 8751) \\
\text { Clinical assistant }(25 \% \text { salary) } \\
\text { Milage for community sisters, approximately } 22 \text { p a mile } \\
\text { Total } \\
\text { Cost per visit ( } 7871 \text { visits) }\end{array}$ & $\begin{aligned}(£) \\
2470 \\
43755 \\
1000 \\
7933 \\
55138 \\
6\end{aligned}$ & $94^{(\mathrm{say}, £ 55000)}$ \\
\hline \multicolumn{3}{|l|}{ Hospital costs } \\
\hline $\begin{array}{l}\text { Sisters-2 working } 30 \text { hours at } £ 5973 \text { a year } \\
\text { Staff nurses } \\
1 \text { working } 30 \text { hours } \\
2 \text { working } 20 \text { hours at } £ 3131 \\
\text { State enrolled nurse working } 20 \text { hours } \\
\text { Nursing auxiliary working } 25 \text { hours } \\
\text { Total }\end{array}$ & $\begin{array}{r}11946 \\
4696 \\
4696 \\
6262 \\
2859 \\
2855 \\
28618\end{array}$ & (say, $£ 30000)$ \\
\hline Total nursing costs & & $£ 85000$ \\
\hline
\end{tabular}

This is cheap compared with the costs of inpatient treatment for a similar number of patients. Assuming patients admitted for a circumcision spend two days, an inguinal hernia three days, an orchidopexy four days, and other procedures one day in hospital the cost would be $£ 300000$ a year. Thus a saving of $£ 215000$ a year could be made. Unfortunately, inpatient bed usage is not $100 \%$ and to carry out the same workload on an inpatient basis would require 10 beds working at $66 \%$ efficiency. The cost of this inpatient service to the Department of Health and Social Security would be in the order of $£ 365000$ a year. Confirmation of this may be seen in table III, which shows the increase in operative workload in Southampton comparing the three year period of $1966-8$ with $1981-3$ achieved with one additional inpatient and six day beds. There was a $300 \%$ increase in turnover.

\begin{tabular}{lcc}
$\begin{array}{l}\text { TABLE III-Comparison of } \\
\text { workload, } 1966-9\end{array}$ and 1981-3 & surgical \\
\hline & $1966-9 *$ & $1981-3 \dagger$ \\
\hline $\begin{array}{l}\text { Admissions } \\
\text { Operations }\end{array}$ & 1051 & 3170 \\
Day operations & - & 2322 \\
\hline *35 beds. & 1157 \\
\hline 36 beds and six day beds.
\end{tabular}

\section{Discussion}

The primary health care team is centred around the general practitioner, who cares for a population with the help of a midwife, health visitor, and district nurse. The midwife is the only member of the team who looks after a specific group of patients in the community. The district nurse is responsible

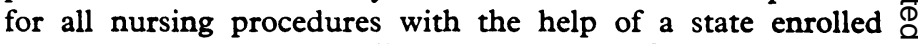
nurse and a nursing auxiliary irrespective of the age of the patient. The diploma of the registered sick children's nurse is not required as part of district nurse training; this leaves deficiencies in the service to children, who comprise $20 \%$ of the 


\section{Increase in fees}

The revised Departmental schedule of medical fees has been issued to central government departments to take account of the changes agreed with the BMA's private practice and professional fees committee as part of the triennial review.

The most important changes are those to the Ministry of Defence schedule. The complex Pulheems examination now attracts a fee of $£ 18 \cdot 40$, backdated to 1 January 1985, and the locum tenens providing evening and night cover in the temporary absence of serving medical officers will be paid $£ 35 \cdot 30$ from the same date. The previous fees were $£ 14$ and $£ 23$ respectively. In the DHSS schedule the members of medical boards will receive $£ 43.40$ a session. The chairman of a single doctor board will continue to receive $£ 50$.

Full details are available from regional offices and members should quote their current membership number and reference FS3 (DHSS); FS4 (Ministry of Defence); FS5 (Employment Service Division, Department of Employment); FS6 (Department of Transport); FS7 (Home Office Prison Department); FS8 (Criminal Injuries Compensation Board); FS9 (Lord Chancellor's Department); or FS10 - fees paid by the Employment Medical Advisory Service.

Following the publication of the 15 th report of the Doctors' and Dentists' Review Body supplements 17 and 18, which list certain fees within the remit of the review body, have been revised, as has fees supplement 35 , which gives recommended rates for deputising doctors, which are linked to review body recommendations. These supplements are available from regional offices.

\section{Extending the Ombudsman's powers}

The government intends to introduce amending legislation to enable the Parliamentary Commissioner for Administration to investigate allegations against non-departmental public bodies"quangos." The decision arises from a recommendation by the Select Committee on the Parliamentary Commissioner for Administration. The commissioner investigates complaints referred to him by members of parliament from members of the public who claim to have suffered injustice as a result of maladministration. The following organisations would be affected if the commissioner's powers are extended: the Medical Research Council, the Medical Practices Committee, the Scottish Medical Practices Committee, and the Central Council for Education and Training in Social Work.

\section{Medicines: information to patients}

The GMSC has approved the following response to the ABPI on the special aspects concerned in providing information to patients on their medicines.

"There is an increasing demand from patients for information on their medication. Any acceptance in principle of giving such information must be qualified by a recognition that the general practitioner should have the option of withholding information. There will be occasions when it will be therapeutically counterproductive to give certain details. Of course, a general practitioner's discretion will only extend to his prescriptions and not to over the counter dispensing.

"A code of practice should recommend standard ised layout including details of what the preparation contains, what it is intended to do, how to get the best advantage from it, what side effects, and an indication that if the patient remains unwell he should consult his doctor. Details should not be dosage related. More than one level of information could usefully be given on the same leaflet.

"The responsibility for writing and updating the information should be the manufacturer's

"Manufacturers should provide inserts as part of original pack dispensing. Similar leaflets, etc, should be available to pharmacists for broken unit dispensing.

"Information on medicines should be available to general practitioners in a compendium and include details of the information given on package inserts and leaflets.

"Information inserts are covered by 1977 regulations, but whether or not the information is given as package inserts, the DHSS will have a review role. The ABPI and the profession must participate in that review. A code of practice could usefully cover a reviewing mechanism.

"It should be the responsibility of the manufacturer to ensure the accuracy of all information and conformity of such information.

"From the doctors' point of view, he has a duty in the provision of care to give appropriate advice to patients. He will be assisted in this by accurate and informative inserts. A similar position applies ethically. There are advantages in the aggregation of information from several sources: the doctor's personal advice will reinforce the printed statements provided.

"The manufacturer should bear the cost.

"The monitoring of the effects of providing such information, perhaps after initial trials, is desirable. The industry, taking such advice as it considers necessary could do this."

\section{Change of doctors' job titles and the review body}

The Department of Health has confirmed that doctors working in National Health Service posts for which a medical qualification is required will continue to be remunerated under the terms of the review body arrangements. There had been some concern that where it was proposed to redesignate the post of regional medical officer to, for example, chief medical adviser this would change the traditional grading structure for regional medical staff.

The BMA raised this point with the DHSS, which has replied as follows: "With regard to the specific question asked, regional medical officer, district medical officer, and specialist in community medicine are grades rather than job titles. Provided the grade in which the community physician is employed is clearly stated in the contract, there should be no problems in the employing authorities adopting job titles, which they consider reflect the individual job descriptions more precisely." population. It therefore seems desirable for the formation of a district nursing service that caters for the needs of childrenthat is, one in which the professional nursing staff are adequately trained and experienced in the care of the sick child.

The Court report stated, "the importance of the family must be reflected in the organisation and delivery of health services for children." 10 The 1976 report recommended the introduction of general practitioner paediatricians, child health visitors, and child health nurses. These were to be geographically based and to provide health in the community with the help of the consultant community paediatrician. In Southampton in 1969 a district nurse service was established for the care of children after day surgery and this has since expanded to provide the additional services that we have described.

Our experience in Southampton with community paediatric sisters would support the recommendations of the Court report and would even suggest that as well as improving the care for children such a service is economical and not a luxury. Any new service always requires careful appraisal and a willingness on the part of the medical and nursing professions to adapt to modern demands whether they be clinical or economic.

\section{References}

1 Atwell JD, Burn JMB, Dewar AK, et al. Paediatric day case surgery. Lancet 1973 ;ii: $895-7$

2 Atwell JD. Changing patterns in paediatric surgical care. Ann R Coll Surg Eng 1978;60:375-83.

Gow M, Atwell JD. The role of the children's nurse in the community. $\mathcal{F}$ Pediat Surg 1980 ;

rgman AB, Shrand $\mathrm{H}$, Oppe TE. A pediatric home care program in Londonten years experience. Pediatrics 1965:36:314-21.

uinton D, Rutter M. Early hospital admissions and later disturbances of Ded Child Neurol 1976;18:447-59.

6 Nicoll JH. The surgery of infancy. $\mathrm{Br}$ Med $\mathcal{f} 1909 ;$;ii :753-4

7 Lawrie $\mathrm{R}$. Operating on children in day cases. Lancet 1964 ;i : 1289-91. Dassociation/British Association of Paediatric Surgeons. Day care in hospitals. London: BPA/BAPS, 1975.

10 Committee on Child Health Services. Fit for the future. London: HMSO, 1976 (Court report.)

(Accepted 20 April 1985 